\title{
Improving the Accountability of the EU Budget's Multi-Level Implementation: Strengthening the Contribution of the European Court of Auditors
}

\author{
Gabriele Cipriani* \\ Former Director, European Court of Auditors, Luxembourg \\ Corresponding author: Gabriele Cipriani, Email: ciprig@pt.lu
}

(Received 26 March 2021; accepted 11 April 2021)

\begin{abstract}
EU spending - more than $€ 1.800$ billion for the next seven years-is spread over a large number of programs and financial mechanisms. Implemented under the Commission's responsibility, its day-to-day management is mostly ensured by a plurality of actors, in particular by member states' nominated bodies. This unique context places the responsibility to undertake influential audit work that could support the EU achieving longterm benefits on the European Court of Auditors (ECA). In this respect, this Article highlights a number of issues. First, this Article discusses the annual audit opinion, to which the ECA devotes at least $40 \%$ of its audit capacity - about 400 auditors—despite the limited assurance it provides. This Article argues that the audit opinion should focus on the operation of the Commission's internal control framework and enlarge its scope to "value for money," thus fostering responsibility at management level and sustaining the emergence of a performance culture. Furthermore, to fully capture the synergies, the risks of double funding and competition between different programs pursuing similar objectives-for example, through cohesion, transport, energy, and research spending - the ECA should undertake a scrutiny across its audit chambers' thematic responsibilities. The ECA should also consider increasing the number of member states covered by its performance reports. Moreover, the ECA's recommendations would benefit from an indication about their importance, and their followup should be extended at member states' level. Finally, this Article welcomes the ECA's intention to assess the added value of EU spending as compared to national spending alone, hence opening up the prospect of an ECA performance "assurance" assessment.
\end{abstract}

Keywords: EU Budget Accountability; EU added value; European Court of Auditors institutional relevance

\section{A. Introduction}

Originating from the merger of a portion of each country's national sovereignty made subordinate to the common interest, ${ }^{1}$ the European Union (EU) acts as a complementary, rather than competitive, system of decision-making founded on the rule of law. ${ }^{2}$ The very essence of what the EU is

\footnotetext{
${ }^{\star}$ The author is a retired former director of the European Court of Auditors.

${ }^{1}$ Jean Monnet, Address Given to the Inaugural Session of the High Authority of the Coal and Steel Community (Aug. 10, 1952), at 2, translation at https://www.cvce.eu/obj/Address_given_by_Jean_Monnet_Luxembourg_10_August_1952-en218b0df9-f81d-43d5-aecb-d1c6aecba604.html.

${ }^{2}$ Treaty of Lisbon Amending the Treaty on European Union and the Treaty Establishing the European Community, art. 2, Dec. 13, 2007, 2007 O.J. (C 306) 1 [hereinafter Treaty of Lisbon]. 
about is that, in certain areas, action at the EU level would make Europe stronger and achieve more than the member states could do acting in isolation. This means being additional or complementary to national efforts rather than filling in gaps left by shortcomings of national policies. ${ }^{3}$ This rationale is regularly evoked in the framework of the EU budget under the concept of "European added value" (EAV), which is exemplified by the expectation that "spending at EU level means a better deal for citizens than spending at national level."4

A long-time key paradigm of the EU budget - the traditional capping of its overall resources slightly in excess of $1 \%$ of total member states' Gross National Product (GNI), ${ }^{5}$ or about $€ 160$ billion/year (2021) - has been cleared away by the outbreak of the Coronavirus pandemic. To help the European economy back on its feet, member states have accepted a significant rise of EU funding for the next seven years, reaching a yearly average of about $€ 260$ billion. ${ }^{6}$ Although this is meant to be temporary, such unprecedented increase in funding will bring the volume of EU finances closer to the 2 to $2.5 \%$ of member states' joint GNI that the MacDougal report considered-more than forty years ago-as a minimum to achieve a perceptible macroeconomic effect on the EU's economy as a whole.

In the EU institutional framework, the European Court of Auditors (ECA) is entrusted with the responsibility of scrutinizing the use of EU funds. This Article examines how the EU's "financial conscience" 8 provides assurance to taxpayers as well as objective and reliable information that can help responsible authorities save money and work more efficiently. The analysis also identifies some issues that would deserve consideration with a view to improving the ECA's own performance and, ultimately, the EU budget's accountability process.

The ECA's mission has to be put in the context of unique budget arrangements that are designed to mirror the balance of powers and the share of competences between the EU as a territorial collectivity and its member states. A bird's-eye view of this unequalled system, rather unsympathetic to reform, ${ }^{9}$ would point to three main features.

\footnotetext{
${ }^{3}$ See European Commission, Reflection Paper on the Future of EU Finances, at 11, COM (2017) 358 final (June 28, 2017). EU action should be subject to a clear assessment of "the existence, scale and consequences of a problem and the question whether or not Union action is needed." Interinstitutional Agreement of 13 April 2016 Between the European Parliament, the Council of the European Union and the European Commission on Better Law-Making, 2016 O.J. (L 123) 1 (EU), paras. 12-13. Ex ante impact assessments are required for Commission legislative or nonlegislative initiatives, delegated acts, and implementing measures expected to have significant economic, environmental, or social impacts. They should provide to the EU legislative authorities, on a comparative basis, a range of feasible policy options addressing the problem, in particular whether there is a need for spending at EU level and/or non-budgetary measures - such as legislative, regulatory and coordination actions. The efficient allocation of resources at both the EU and national level, so as to deliver to best effect, might suggest ultimately to take no action at EU level.

${ }^{4}$ European Commission, The EU Budget Review, at 5, COM (2010) 700 final (Oct. 19, 2010); see also GABRIELE CIPRIANI, The EU Budget: Responsibility Without Accountability? 6-9, 73-75 (2010); Eulalia Rubio, The "Added Value" In EU Budgetary Debates: One Concept, Four Meanings, 2011 Notre Eur. Pol’y Brief 28 (2011).

${ }^{5} \mathrm{GNI}$ represents total primary income receivable by resident institutional units: compensation of employees, taxes on production and imports less subsidies, property income, gross operating surplus, and gross mixed income. It corresponds to the better known gross domestic product minus primary income payable by resident units to non-resident units, plus primary income receivable by resident units from the rest of the world. See Monitoring GNI for own resource purposes, EUROSTAT (Dec. 22, 2020), https://ec. europa.eu/eurostat/statistics-explained/index.php/Monitoring_GNI_for_own_resource_purposes\#Introduction.

${ }^{6}$ See European Council, Conclusions of 17-21 July 2020, doc. EUCO 10/20, (July 21, 2020). The Next Generation EU Instrument (NGEU) represents an extraordinary recovery effort— $€ 750$ billion—on top of the EU's long-term budget, or "multi-annual financial framework" (MFF), for 2021-2027—€1.074 billion. Under the NGEU, money would be borrowed on markets by the Commission on behalf of the EU and guaranteed by the EU budget. The debt would be repaid over a long term, possibly by 2058.

${ }^{7}$ European Commission, Report by the Study Group on the Role of Public Finance in European Integration, Rapporteurs: D. MacDougal et al., at 17 (Apr. 1977).

${ }^{8}$ Hans Kutscher, President of the Court of Justice, Address at the swearing-in of the ECA's first members (Oct. 25, 1977), at 2, translation at https://www.cvce.eu/obj/address_by_hans_kutscher_25_october_1977-en-61ae5ec8-62d8-4844-be8e4c5212049f31.html.

${ }^{9}$ Reviews of the EU Budget carried out in the past led to limited change only. For the last review, conducted by the Commission services, see European Commission, Spending review, SWD (2018) 171 final (May 2, 2018).
} 
First, because the EU has not been given the power to raise taxes on its own, the EU and national budgets compete for the same revenues. This means that a portion of overall national taxation is assigned to the EU in form of member states' contributions. ${ }^{10}$ Yet, as if EU revenue "grows on trees," such transfer is made impalpable to EU citizens, thus lessening the risk for national governments to face a political cost to raise such revenue. ${ }^{11}$ Even the unprecedented two-thirds increase of EU funds discussed above was not enough to breach the consolidated stance of keeping EU revenue outside taxpayers' sight.

Second, the EAV principle recalled earlier implies selectivity, concentration of resources, and adequate implementation arrangements, as well as "clear and visible benefits for the EU and for its citizens" failing, which diminishes trust in the EU. ${ }^{12}$ Indeed, "[w]hen ambitious objectives are pursued with limited resources and weak implementation mechanisms, we have a recipe for disappointment." ${ }^{13}$ In this respect, when asked if they think that the EU budget provides good value for money, more than $40 \%$ of EU citizens believe that this is not the case. Most importantly, more than a quarter of Europeans express no opinion on this subject. ${ }^{14}$ Member states' unanimity required to set the seven years "financial framework" (MFF) ${ }^{15}$ makes finding a compromise between different rationales and national stances inevitable. Such compromise is founded on the understanding that, as a counterpart to their contributions to the EU budget, most of EU expenditure is handed back to member states through a delicate balance of allocative, redistributive, and stabilizing measures covering around thirty policy areas and sixty spending programs. ${ }^{16}$ These measures are generally embedded with grandstanding and politically attractive all-inclusive objectives, ${ }^{17}$ yet often lack the critical mass to achieve and display a noticeable impact. This

\footnotetext{
${ }^{10}$ Gabriele Cipriani, Financing the EU Budget: Moving Forward or BaCKWARds? 1-27 (2014) (stating that member states' contributions are mainly based on Gross National Income and Value Added Tax assessment basis).

${ }^{11}$ Gabriele Cipriani, Making Taxpayers' Contributions to the EU Budget Visible, Towards Greater Transparency and Legitimacy, in Financial Accountability in the European Union 247-49 (Paul Stephenson, María-Luisa SánchezBarrueco \& Hartmut Aden eds., 2020).

${ }^{12}$ European Court of Auditors (ECA), Response to the Commission's Paper "Reforming the budget, changing Europe", para. 8 (Apr. 2008), https://www.eca.europa.eu/Lists/News/NEWS0804_10/NEWS0804_10_EN.PDF; ECA, Audit Strategy 20182020, at 4 (July 2017), https://www.eca.europa.eu/Lists/ECADocuments/STRATEGY2018-2020/STRATEGY2018-2020_EN. PDF.pdf.

${ }^{13}$ European Council, The Reflection Group on the Future of the EU 2030, at 5 (May 2010), https://espas.secure.europarl. europa.eu/orbis/corporate-author/reflection-group-future-eu-2030.

${ }^{14}$ European Commission, Europeans and the European Union Budget, at 7 (May 2015), https://ec.europa.eu/ commfrontoffice/publicopinion/archives/eb/eb83/eb83_budget_en.pdf. EU citizens are also very divided in their assessment of whether EU financial resources fit the objectives set and consider that what should be the priorities for the EU's budget are only imperfectly translated into how the budget is spent. See European Commission, Europeans and the EU budget, at 4, 17 (Nov. 2019), https://europa.eu/european-union/about-eu/eu-budget/expenditure_en.

${ }^{15}$ To guarantee stability and predictability of EU expenditure, the MFF determines the overall amount of the resources that can be called upon over the period and the maximum amounts that can be spent each year on broad policy areas. This translates into a limited flexibility in case of unforeseen needs with the annual budget essentially pre-determined.

${ }^{16}$ See Cipriani, supra note 10, at 75-79; Gabriele Cipriani, The EU Budget, in The Routledge HandBook OF European Public Policy 146-48 (Nikolaos Zahariadis \& Laurie Buonanno eds., 2018). While economic theory would distinguish fiscal functions according to three categories - allocation, re-distribution, and stabilization — only a few EU spending programs conform fully to this characterization. See Richard \& Peggy Musgrave, Public Finance in Theory and Practice 3-14 (1989). Promoting research, mitigating the effects of climate change, supporting border control and immigration policy, or defense cooperation would naturally fall into the "allocation" concept as they benefit to all citizens, irrespective of circumstances. Yet, while the Treaty provisions concerning the two main spending areas, agriculture and cohesion, aim to incentivize efficiency, investment and production that are typical of the allocative concept, they also make room for promoting wealth and income re-distribution. See Consolidated Version of the Treaty on the Functioning of the European Union arts. 39-41, 17476, May 9, 2008, 2008 O.J. (C 115) 47 [hereinafter TFEU]. Furthermore, these policies also involve a stabilization role by maintaining market stability in times of market disturbances-agriculture-or stimulating the economy through public investment in periods of economic recession — cohesion. Nonetheless, the main instruments of stabilization are of macroeconomic nature and point in particular to monetary and fiscal policy which is outside the EU budget remit.

${ }^{17}$ The whole set of spending measures entail about sixty general objectives and almost 230 specific objectives.
} 
context provides leeway to configure EU policies according to national preferences, especially in the areas where funds are preallocated to member states by the $\mathrm{MFF}^{18}$ and the main management decisions are taken by their own bodies. ${ }^{19}$ Such context incentivizes funding of "Europeanized" national measures displaying their impact as much as possible within national borders, instead of measures with a transnational dimension - which are out of reach of any individual member state and therefore have a potentially higher EAV. Ultimately, reflecting a spending rather than a performance culture, funding may be allocated primarily where it is likely to be fully spent rather than where it addresses key needs and produces results. ${ }^{20}$

Third, despite the multi-level structure applying to most of EU spending, ${ }^{21}$ the unitary and selfstanding nature of the EU budget relies on the Commission's role of promoting "the general interest of the Union" 22 and executing "the budget and manage programmes," which it is alone responsible for, regardless of whether or not it manages the funds directly. ${ }^{23}$ Yet, regarding member states' responsibilities, the Commission discards the ownership for budgetary implementation as a whole. At the same time, national bodies in charge of EU budgetary tasks remain accountable to their governments, which in turn are accountable either to their national parliaments, or to their citizens. ${ }^{24}$ Yet, the key features of the system—such as the MFF agreed unanimously as a global package of mostly pre-allocated expenditures and also citizens' tax unconsciousnessdo not play as an incentive for national governments in rendering an account at national level for the use of the revenue transferred to the EU. This means that while in principle EU citizens should be able to hold each layer of government separately accountable for its activities, in practice, there is an accountability gap that undermines the possibility to initiate timely and effective redress, as well as to hold those responsible to account. The increased risk of waste and misuse of

\footnotetext{
${ }^{18}$ Funds pre-allocations, representing about $80 \%$ of EU expenditure, are amounts assigned to member states in areas such as Cohesion policy, Common Agricultural policy, European Maritime and Fisheries Fund, and the nuclear decommissioning assistance program. See Budget pre-allocations, EUROPEAN COMMISsION, https://ec.europa.eu/info/strategy/eu-budget/longterm-eu-budget/eu-budget-2014-2020/spending/pre-allocations_en.

${ }^{19}$ For example, it is for national delegated bodies to assign EU funds to farmers and to decide the projects to be funded under rural development, fisheries, and structural and investment funds, as well as to control their implementation and make the corresponding payments to the beneficiaries.

${ }^{20}$ See ECA, Future of the CAP, paras. 31-33 (Mar. 19, 2018), =https://www.eca.europa.eu/en/Pages/DocItem.aspx?did= 45498; ECA, Delivering performance in Cohesion, para. 26 (June 20, 2019), https://www.eca.europa.eu/en/Pages/DocItem. aspx?did $=50385$. For example, in Cohesion policy, funds must be spent by the end of the third year after their allocation, otherwise they will be lost for the member state. The usual concentration of spending towards the end of the MFF runs the risk that member states may prioritize spending at the expense of performance and regularity. See ECA, Report on the Performance of the EU Budget - Status at the End of 2019, para. 3.66 (Nov. 9, 2020), =https://www.eca.europa.eu/en/Pages/DocItem.aspx? $\mathrm{did}=53900$; see also ECA, Opinion 4/2020 Regarding the Proposed REACT-EU Regulation and Common Provisions Regulation Governing the ESI Funds, paras. 8, 13 (July 13, 2020), https://www.eca.europa.eu/en/Pages/DocItem.aspx?did=54299.

${ }^{21}$ Only $18 \%$ of the EU budget is directly managed by the Commission. See European Commission, The EU budget at a glance, at 22 (May 2019), https://ec.europa.eu/info/publications/eu-budget-at-a-glance_en. Delegated management functions are mostly exerted by member states' nominated bodies, and also by EU agencies, the European Investment Bank, third countries, and international organizations.

${ }^{22}$ Treaty on European Union, art. 17(1), Dec. 24, 2002, 2002 O.J. (C 325) 5 [hereinafter TEU]. As pointed out by Ponzano, the general interest of the European Union does not necessarily correspond to the addition of national interests, neither does it equate to the lowest common denominator of the different national stances. See Paolo Ponzano, Brèves considérations sur le rôle de la Commission européenne, 2 RDUE 218 (2009).

${ }^{23}$ The Treaties provide that the Commission "shall execute the budget and manage programmes." TEU art. 17(1). It shall do so "in cooperation with the Member States," "on its own responsibility," and "having regard to the principles of sound financial management." TFEU arts. 310.5, 317(1). Member states' cooperation in the budgetary implementation represents a delegation of tasks following the principle of sincere cooperation. TEU art. 4.3. Yet, the implementation of the budget as such is not delegated. For this reason, member states do not participate in the discharge procedure before Parliament and Council. TFEU art. 319. The Commission's ultimate responsibility independently of the implementation mode is stated by Articles 56.1 and 62.3 of Regulation 2018/1046, of the European Parliament and of the Council of 18 July 2018 on the Financial Rules applicable to the General Budget of the Union, 2018 O.J. (L 193) 1 (EU) [hereinafter Financial Regulation].

${ }^{24}$ TEU art. 10.2(2).
} 
power puts the EU budget's legitimacy in the eyes of EU citizens at stake, and this loss of trust in EU policies and institutions represents a key future challenge for the EU. ${ }^{25}$

In light of these challenges, the aim of this Article is to examine the ECA's contribution to the accountability of the EU budget's multi-level implementation. To this end, this Article starts with a description of the ECA's audit mandate and audit powers in Section B. It subsequently examines the concept underlying the establishment of its annual audit opinion, the ECA's priority task. In this respect, this Article brings forward two main issues. First, the narrow scope of the ECA's annual audit opinion limits the assurance that it can provide over the proper use of EU expenditure in Section B(I). Second, the approach based on "error rates" routinely employed by the ECA risks to provide support for wrong incentives and ineffective protection of taxpayers' money in Section B(II). This Article argues that the time is appropriate to rethink how the ECA produces its annual audit opinion. Section B(III) further discusses the significant and growing effort undertaken by the ECA to respond to the demand for performance assessment across policy areas. Acknowledging the crucial contribution of the ECA's performance reports, this Article argues that where the EU budget pursues similar objectives in a cross-cutting perspective-e.g., through cohesion, transport, energy, and research spending - a scrutiny across the ECA audit chambers' thematic responsibilities may be needed to fully capture the synergies and risks of double funding and competition between different programs. Furthermore, broadening the geographical scope of the audit work would enhance the possibility of drawing conclusions beyond the current limited number of member states visited.

Section $C$ deals with the extent to which the ECA's recommendations are accepted and implemented, a key indication of the institution's effectiveness. This Article argues that insufficient information is provided in order for a full picture of compliance to emerge. This pertains to lack of indication as to the significance of the recommendations and the reasons behind the rejection of some of them, as well as the absence of follow-up of recommendations addressed to member states. This raises the question of whether national audit offices should be involved in the follow-up process and, more generally, whether the ECA should have an open data platform of its recommendations to raise public awareness and induce better accountability from those responsible for action.

Section D provides recommendations as to how the ECA could further contribute to the accountability of the EU's budget implementation. First, it deals with the ECA's institutional relevance and describes the main elements to enhance the added value of its annual audit opinion through a wider concept of compliance encompassing "value for money," thus supporting the emergence of a performance culture in Section $\mathrm{D}(\mathrm{I})$. In addition, focusing on the effectiveness of internal control arrangements and the reliability and relevance of the Commission's financial and performance reporting, the annual audit opinion will foster responsibility at management level. The last part, Section D(II), deals with the EAV's assessment of EU spending and how the ECA can contribute to make this concept operational. This Article argues that, in consultation with the Commission, the ECA could develop audit criteria that identify whether EAV has been achieved.

\section{B. The European Court of Auditors, a Fundamental Pillar of EU Accountability}

The ECA is a collegial body made up of twenty-seven members-one for each member state- and organized into five audit chambers. It has an overall yearly budget of approximately 150 million euros, or about $1.5 \%$ of the EU's institutions administrative expenditure. ${ }^{26}$

\footnotetext{
${ }^{25}$ European Commission, Draft General Budget for 2020, Section V, Court of Auditors, at 3, COM (2019) 600 (July 5, 2019); see also ECA, Audit Strategy 2018-2020, supra note 12, at 4. On the accountability for the EU budget, see CIPRIANI, supra note 4; see also Gabriele Cipriani, The EU Budget, the Accountability Gap and a Possible Way Forward, in THE NEw POLITICS OF THE European Union Budget 225-58 (Stefan Becker, Michael W. Bauer \& Alfredo De Feo eds., 2017).

${ }^{26}$ European Union's general budget for the Financial Year 2021, 2021 O.J. (L 93) 1983 (EU).
} 
The ECA is a fully independent EU institution with a broad and global mandate, encompassing financial, compliance, and performance audit. ${ }^{27}$ The Treaty leaves the ECA to determine and implement its own duties. It thus enjoys a discretionary power in deciding audit priorities, applying standards and methodologies as appropriate to the EU context, and allocating its resources accordingly.

The ECA audit mandate is exclusive. By contrast with the EU budget implementation, there is no such thing as a "shared" audit function. To carry out its audits, the ECA can take advantage of national audit offices' cooperation, ${ }^{28}$ but in reality this is limited to the exchange of best practices and discussion of EU-related issues. ${ }^{29}$ Despite initial intentions, ${ }^{30}$ the possibility that national audit offices would audit EU funds in their country on behalf of the ECA has not materialized. ${ }^{31}$ Apart from sporadic cases, the possibility of cooperative audits has not been considered mutually advantageous and cost-effective.

The ECA can perform audits anywhere within and outside the Union, including in the premises of physical or legal persons having received EU funds or being responsible for its revenue. It has a right of access to all documents necessary to its work, starting from the very first act potentially generating revenue or expenditure. ${ }^{32}$

The diffused responsibilities for the budgetary implementation discussed earlier ${ }^{33}$ have prompted the ECA to consider both the Commission, as "main auditee," and the competent authorities, "other auditees," as subjected to its audit. This implies that the ECA has to seek the information "necessary to carry out its task" ${ }^{34}$ from a plurality of counterparts whose readiness to provide timely and full information is not always ensured. ${ }^{35}$ Lack of cooperation negatively affects the planning and scope of the audit work, delaying ultimately the finalization of audit

\footnotetext{
${ }^{27} \mathrm{See}$ International Standards of Supreme Audit Institutions ("INTOSAI") Standard 100, Fundamental Principles of PublicSector Auditing, para. 22. INTOSAI-P 1, The Lima Declaration of Guidelines on Auditing Precepts, para. I.4.3, http://www1. worldbank.org/publicsector/pe/befa05/LimaDeclaration.pdf (providing that legality, regularity, economy, efficiency, and effectiveness of financial management are basically of equal importance). It is for each audit office to determine its priorities on a case-by-case basis.

${ }^{28}$ TFEU art. 287.3.

${ }^{29}$ See ECA Landscape Review, EU Action on Energy and Climate Change, at pt. II (June 21, 2017), https://www.eca.europa. eu/Lists/ECADocuments/LR17_01/LR_ENERGY_AND_CLIMATE_EN.pdf (providing an overview of the EU national audit offices' work in energy and climate change).

${ }^{30}$ See European Parliament, The Case for a European Audit Office 27 (1973); see also Claus-Dieter Ehlermann, Der Europaische Rechnungshof 36 (1976); Antonino De Stefano, Il contributo della Corte dei Conti italiana e delle altre Corti dei Conti nazionali alla istituzione della Corte dei Conti delle Comunità, in InTERventi Comunitari Nelle AreE Depresse e Nel Mezzogiorno D’Italia: Controlli Comunitari e Nazionali 85 (1982).

${ }^{31}$ As provided for by international standards, this would imply an assessment by the ECA of the suitability of such work that could be perceived as a loss of independence of national audit offices. See INTOSAI GOV 9150, Coordination and Cooperation Between SAIs and Internal Auditors in the Public Sector, (2009), http://www.psc-intosai.org/lumis/portal/file/fileDownload. jsp?fileId=8A81881E747486F3017478D14BE71617\&inline=1; International Federation of Accountants (IFAC)-ISA 610, Using the Work of Internal Auditors and IFAC-ISA 600, Audits of Group Financial Statements - Including the Work of Component Auditors, (Mar. 2013), https://www.ifac.org/system/files/publications/files/ISA-610-(Revised-2013).pdf. This was the ground for stating in the Treaty that the ECA and national audit offices "shall cooperate in a spirit of trust while maintaining their independence.” TFEU art. 287.3 (1), sentence 3 (following amendment by the Treaty of Amsterdam 1997). The reference to independence reflects the differences of audit mandates, methodologies, and reporting arrangements.

${ }^{32}$ Financial Regulation, supra note 23, at art. 257.

${ }^{33}$ See supra Section A.

${ }^{34}$ TFEU art. 287.3(1)(2).

${ }^{35}$ For examples of difficulties concerning the transmission of relevant documents, see ECA, Annual Report Concerning the Financial Year 2018, at 191 para. 9.13, 284 para. 19 (July 18, 2019), =https://www.eca.europa.eu/en/Pages/DocItem.aspx?did= 50534; ECA, Annual Report Concerning the Financial Year 2019, at 305 para. 19 (Sept. 24, 2020), =https://www.eca.europa.eu/ en/Pages/DocItem.aspx?did=53898; ECA special report, 29/2016 Single Supervisory Mechanism - Good Start But Further Improvements Needed (Oct. 18, 2016); ECA special report, 14/2017 Performance Review of Case Management at the Court of Justice of the European Union (Sept. 5, 2017); ECA special report, 17/2017 The Commission's Intervention in the Greek Financial Crisis (Oct. 3, 2017); ECA special report, 23/2017 Single Resolution Board: Work on a Challenging Banking Union Task Started, But Still a Long Way to Go (Nov. 28, 2017); ECA special report, 2/2018 The Operational Efficiency of the ECB's Crisis Management for Banks (Dec. 12, 2017).
} 
reports. Furthermore, the clearing of audit findings concerning multi-level managed programs generally requires two stages, first with the delegated bodies and then with the Commission. ${ }^{36}$

In addition to its two main annual reporting obligations, ${ }^{37}$ the ECA can submit observations at any time. There is actually no month without an ECA publication reporting the outcome of its audits or assessing draft legislation. This provides a major input to the legislative and political process. ECA's observations do not constitute res judicata - an exclusive competence of the European Court of Justice 38 - and can therefore not compel EU institutions and states to follow its pronouncements. Nevertheless, the latter carry reputational weight and represent an authoritative opinion at the basis, inter alia, of the annual discharge process before Parliament and Council. ${ }^{39}$

In the remainder of this section, this Article will discuss the challenges that are currently impairing the capacity of the annual audit opinion to work as a functional accountability mechanism in the EU multi-level governance system. It will thereafter examine the impact of ECA's performance reports and the room for broader coverage of EU policy objectives.

\section{The "Statement of Assurance" on Legality/Regularity: A Limited Assurance}

The "statement of assurance" 40 (annual audit opinion) has been introduced by the Treaty of Maastricht (1992). The absence of precedent in national audit offices ventured the ECA into the unknown, ${ }^{41}$ requiring it to exercise significant judgement regarding the type, scope, and methodology of its annual audit opinion. While the Treaty eventually gave considerable margin for interpretation as to what was required, the ECA set up an elaborate construction and made the annual audit opinion its priority task.

Built on a quantitative approach, the annual audit opinion's methodology is based on testing a random, statistically representative, sample of financial transactions with a view to calculate a global estimate of non-compliance in the form of a percentage of "error." 42 This approach revealed a number of uncomfortable frailties and uncertainties.

The exclusion from the scope of the annual audit opinion of sound financial management, or "value for money," 43 a concept raised as a criterion for the budgetary implementation by the same

\footnotetext{
${ }^{36}$ While member states' delegated bodies have the opportunity to comment on ECA preliminary findings, the ECA counterpart during the finalization of draft reports is the Commission alone-or another responsible EU institution or body-whose replies are published together with ECA reports. See Financial Regulation, supra note 23, at arts. 258.4, 259.1(6)(7).

${ }^{37}$ This refers to the "statement of assurance" on the reliability of the EU consolidated accounts and the legality and regularity of transactions, and the annual report. TFEU arts. 287.1(3), 4(1). In practice, the central part of the annual report is represented by the "statement of assurance."

${ }^{38} \mathrm{By}$ reference to the categories of the European Union's legal acts set out in Article 288 TFEU, the ECA's observations are soft law instruments, to be ranked on the same level as recommendations and opinions.

${ }^{39}$ TFEU art. 319.

${ }^{40}$ The Treaty formulation is a "statement of assurance as to the reliability of the accounts and the legality and regularity of the underlying transactions." TFEU art. 287.1(2).

${ }^{41}$ Gilberto Moggia, The Origins of the Statement of Assurance (1990-1995) - Actors, Facts and Circumstances, ECA Subject Brief $3 / 2020$, at 4 .

${ }^{42}$ The annual audit opinion relies mainly on ECA's direct testing. Notably in the area of Cohesion, ECA's assessment is based - since 2017 — on a review and, when necessary, re-performance of national audit authorities' checks of sampled transactions. For the 2019 annual audit opinion, the sample consisted of 747 payments to beneficiaries across all spending areas. The number of transactions tested has been reduced significantly since 2014. Compliance is tested on the basis of all EU and national provisions applying relevant European Union law and having a legal impact on those transactions.

${ }^{43}$ The concept of "value for money" has three dimensions: Economy, efficiency, and effectiveness. The principle of "economy" requires that the resources used shall be made available in due time, in appropriate quantity and quality, and at the best price. "Efficiency" is characteristically a managerial value consisting in essence of maintaining a good ratio between resources employed and results attained. A related value is "effectiveness," which basically consists of ensuring that the performance of public administration is successful in achieving the goals and solving the public problems set for it by law and government. See OECD, European Principles for Public Administration, Sigma Paper 27, at 13-14 (Jan. 1, 1999), http://www. sigmaweb.org/publicationsdocuments/36972467.pdf. These principles are part of EU financial rules. See Financial Regulation, supra note 23 , at art. 33.
} 
Treaty of Maastricht, ${ }^{44}$ bears witness to a narrow interpretation of the requirements for EU spending, matching furthermore the ECA audit mandate only partially. ${ }^{45}$ The ECA's first-ever report on the overall performance of the EU budget adopted in $2020^{46}$ does not bridge this gap in the audit scope, as it does not represent a "performance statement of assurance," or an "assessment of the soundness of financial management" 47 of spending programs against performance criteria. It also provides no attestation on Commission's performance reporting.

The consequence of the misalignment between compliance and performance audit can be illustrated by the EU fully funding direct payments to support farmers' incomes. This spending area, for an annual cost of more than $€ 41$ billion, is considered by the ECA annual audit opinion as "free from material error." ${ }^{48}$ Yet, due to the scope limitation mentioned earlier, this does not mean that resources have been spent wisely. On the contrary, the ECA's performance audits indicate that such a scheme is neither the most efficient way of ensuring a viable income nor appropriate for addressing many environmental and climate concerns, bringing about a minor impact in changing farming practices and improving biodiversity. ${ }^{49}$ The above raises the question as to what extent an expenditure can be considered legal or regular if it does not meet "value for money" requirements.

Due to the legislative arsenal of EU and national provisions ruling the budget implementation, compliance of a given financial transaction is often a matter of interpretation. It is not uncommon that the ECA needs to reassess its initial conclusions on the basis of counter-assertions put forward by member states' bodies and the Commission. ${ }^{50}$ Cases of persistent disagreements between the ECA and the Commission are sometimes acknowledged in the ECA annual report. ${ }^{51}$

\footnotetext{
${ }^{44}$ TFEU art. 317(1) refers twice to the principles of sound financial management. The Treaty of Lisbon (2007) has reiterated the same principles in Article 310.5, sentence 1.

${ }^{45}$ See supra Section B.

${ }^{46} \mathrm{ECA}$, Report on the Performance of the EU Budget, supra note 20. Previously, starting from the financial year 2010, the ECA annual report included a dedicated chapter about performance, titled "Getting results from the EU budget." It should be noted that, since 2014, the ECA has examined aspects of performance-in particular for Cohesion-for some of the transactions selected for the testing of legality/regularity in the frame of its annual audit opinion. While providing valuable insight, this work was, however, not designed to contribute to the audit opinion's overall conclusion. Its added value for the overall assessment of program performance is rather limited.

${ }^{47}$ Financial Regulation, supra note 23, at art. 258.2 (providing that the ECA annual report "shall contain an assessment of the soundness of financial management"). The European Parliament requested the ECA to "provide the discharge authorities with an assessment in terms of both compliance and performance, of each European policy." See European Parliament, Resolution of 26 March 2019 on Discharge in Respect of the Implementation of the General Budget of the European Union for the Financial Year 2017, Section III - Commission and Executive Agencies, para. 242, https://www.europarl.europa.eu/ doceo/document/TA-8-2019-0242_EN.html.

${ }^{48}$ This means that the level of error is below $2 \%$. See infra, Section D(II)(1).

${ }^{49}$ See ECA, special report, Is the Commission's System for Performance Measurement in Relation to Farmers' Incomes Well Designed and Based on Sound Data? (Jan. 13, 2016), https://www.eca.europa.eu/Lists/ECADocuments/SR16_01/SR_ FARMERS_EN.pdf; ECA, EU Support to Young Farmers Should be Better Targeted to Foster Effective Generational Renewal (May 31, 2017), https://op.europa.eu/en/publication-detail/-/publication/2be42d60-7cad-11e7-b2f2-01aa75ed71a1; ECA, Basic Payment Scheme for Farmers - Operationally on Track, But Limited Impact on Simplification, Targeting and the Convergence of Aid Levels (Feb. 7, 2018), https://www.eca.europa.eu/en/Pages/DocItem.aspx?did=45158; ECA, Farmers' Income Stabilisation: Comprehensive Set of Tools, But Low Uptake of Instruments and Overcompensation Need to be Tackled (October 16, 2019), https://www.eca.europa.eu/en/Pages/DocItem.aspx?did=52395; ECA, Biodiversity on Farmland: CAP Contribution Has Not Halted the Decline (May 19, 2020), https:/www.eca.europa.eu/en/Pages/DocItem.aspx?did=53892; ECA, Opinion 7/2018 Concerning Commission Proposals for Regulations Relating to the Common Agricultural Policy for the Post-2020 Period, paras. 2, 27-28, 32 (October 25, 2018), https://www.eca.europa.eu/en/Pages/DocItem.aspx?did=47751; European Commission, Future of the CAP, paras. 14-16 (Mar. 19, 2018), https://ec.europa.eu/info/food-farming-fisheries/ key-policies/common-agricultural-policy/future-cap_en; European Commission, The Commission's Proposal for the 20212027 Multiannual Financial Framework, para. 19 (July 10, 2018), https://ec.europa.eu/info/strategy/eu-budget/long-term-eubudget/2021-2027/negotiations_en; European Commission, The Commission's Legislative Proposals for the Next Multiannual Financial Framework (MFF), paras. 14-15, 22 (Feb. 14, 2019), https://ec.europa.eu/info/strategy/future-europe.

${ }^{50}$ See supra note 36.

${ }^{51} \mathrm{See}$ for example the Commission's replies to paras. 1.30 and 6.14-6.15 of ECA's Annual Report Concerning the Financial Year 2018 (July 18, 2019), supra note 35.
} 
The sample of transactions underlying the estimate of non-compliance is set on the assumption that the different spending areas form a coherent whole and there is one single delivery system for the whole budget. In reality, EU budgetary areas are rather heterogenous and their annual spending path can be uneven, due, for example, to the natural time lag needed for the completion of funded projects. Furthermore, the implementation chain is diffused among a range of administrative models of varying effectiveness. In any given year only few of them are sampled, and not in every beneficiary state and region. In such a complex and diverse underlying background, the "error rate" cannot provide a persuasive "geography" of the legal or regular budgetary implementation across member states-let alone individual delegated bodies. Furthermore, the trend over time of the "error rate" cannot go beyond broad-brush comparisons from year to year and can only leave one guessing the reasons for the ups and downs. ${ }^{52}$

The ECA uses a $2 \%$ "one size fits all" materiality threshold for its annual opinion across policy areas, independently of their risks and peculiarities. ${ }^{53}$ Such threshold has become a de facto synonym for "tolerable risk of error." 54 Derived from financial audits in the private sector, such threshold is not tailored to the EU budget framework, not least because the level of irregularity varies across policy areas. In this respect, it would seem sensible to consider whether the $2 \%$ threshold represents an unreasonable obstinacy for half of EU spending that is characterized by complex funding arrangements. The question is notably whether such complexity can explain that the ECA "error rate" in Cohesion spending is more than twice as much as that for direct payments to farmers. In this respect, the national audit offices could provide useful insight as national budgets fund the same typology of EU measures. At the same time, this could shed light on the comparative cost-effectiveness of EU internal control arrangements in relation to national ones.

Despite conceptual stretching, the "error rate" has no way of speaking for itself. It ultimately represents a symptom whose multiple possible causes and potential spread to the spending area concerned would require further investigation. As this is generally not part of the audit work, the "error" leads mainly to quantify, whenever possible, the financial impact of an irregularity, but it does not identify appropriate treatment avoiding its recurrence. In particular, the quantitative approach is not designed to gather data on the frequency of "errors," and therefore on their systemic character.

For multi-annual programs, characterized by multi-stage payments over several accounting years, ${ }^{55}$ the ECA annual assessment of legality/regularity is provisional by nature, as financial corrections may take place at a later stage, once transactions have been checked by all internal controls $^{56}$ in place and have undergone Commission's clearance.

\footnotetext{
${ }^{52}$ For example, there is no explanation concerning the yo-yo effect of the ECA error estimate in "Competitiveness for growth and jobs"-from 4.1\% in 2016, to 4.2\% in 2017, 2.0\% in 2018 and 4.0\% in 2019-and "Economic, social and territorial cohesion"-from $4.8 \%$ in 2016 , to $3 \%$ in $2017,5.0 \%$ in 2018 and $4.4 \%$ in 2019.

${ }^{53}$ For further discussion on this, see infra Section $\mathrm{D}$ (II)(1).

${ }^{54}$ The Commission's objective is that the level of error is below $2 \%$ at the end of the programs' lifecycle. This objective is a formal requirement for the Cohesion control and assurance framework. See Commission Delegated Regulation 480/2014 of 3 March 2014, art. 28(11), 2014 O.J. (L 138) 5 (EU). See infra, Section D(II)(1).

${ }^{55}$ This concerns in particular structural and investments funds.

${ }^{56}$ Internal control is a built-in dynamic process "that helps an organization to achieve its objectives and sustain operational and financial performance, respecting rules and regulations. It supports sound decision making, taking into account risks to the achievement of objectives and reducing them to acceptable levels through cost-effective controls." European Commission, Revision of the Internal Control Framework, at 2, C(2017) 2373 final (Apr. 19, 2017); see also note 107 and INTOSAI GOV 9100, Guidelines for Internal Control Standards for the Public Sector, https://ms.hmb.gov.tr/uploads/2019/06/6883A22DF8F253B907C7599ED7639A374C05765D2DC7.pdf.
} 


\section{The Proliferation of Error Estimates and the Risks of an "Error"-Centric Culture}

The ECA annual audit opinion has been instrumental in embedding in EU spending programs the concept of "error rate" as a compulsory instrument for measuring compliance. In particular, the Commission has a duty to monitor the level of error during implementation and to provide each year to the budgetary authorities an estimation of such level as well as an estimate of future corrections. ${ }^{57}$

While the ECA provides several estimates of error, ${ }^{58}$ the Commission uses different concepts such as the "risk at payment"-close to the ECA estimate for the level of error-complemented by an estimate of "risk at closure" which takes into account projected future corrections and recoveries. In specific areas, the Commission establishes each year also "residual" error rates per program-or other relevant segments-at member state level taking into account financial corrections that have already been made. ${ }^{59}$ Perceived as a duplication of audit work, such different approaches in presenting "error rates" create the conditions for a "beauty contest," with a potential for divergence ${ }^{60}$ and ultimately confusion as the differences-and their consequences-would remain obscure to most observers. One may wonder whether the exponential increase and variety of audit opinions induce more accountability or just multiply the number of hypotheses to investigate. It is not surprising that Parliament and Council have asked for consistency in assessing legality/regularity. ${ }^{61}$

The "error rate" has become the mainstay of the Commission's "fire alarm" oversight of the budget implementation, reacting ex post to individual warnings, in particular as a result of the ECA's audit work. As an accountability's shortcut, the protection of the EU budget from expenditure incurred in breach of law is meant to be ensured by disallowing EU funds-financial corrections - when the degree of non-compliance exceeds the "tolerable" error. ${ }^{62}$ Yet, a large part of these corrections result in shifting money across projects and measures, with no impact on member states' overall MFF envelopes. Secondly, when these corrections translate into a net loss of funds for member states, these are generally put at the charge of national budgets rather than of EU funds beneficiaries. Thirdly, the deterrence of this instrument and its effectiveness in causing structural repairing effects must be limited if-for example, despite many corrections applied, together with Commission's action plans and guidance-failure to comply with public procurement rules and State aid legislation remains a significant source of errors. Ultimately, financial corrections represent an indicator of failure and missed opportunities, because the objectives initially linked to these funds would not be achieved. They might well put the EU accounts formally "in order," with the risk however of working as a "painkiller," without true healing and relief for the taxpayer.

\footnotetext{
${ }^{57}$ Financial Regulation, supra note 23, at arts. 35.3, 35.4, 36.5 and 247.1.(b)(i).

${ }^{58} \mathrm{An}$ overall estimate of error for the budget as a whole, and specific estimates for some policy areas, complemented each time by a "lower error limit" and an "upper error limit," as well as estimates for high-risk and low-risk expenditure.

${ }^{59}$ European Commission, 2019 Annual Management and Performance Report for the EU Budget, at 56-62, 223-37, COM (2020) 265 final (June 24, 2020).

${ }^{60}$ For example, the Commission claims that when the ECA detects procurement errors and/or the late availability of supporting documents for grants, in a-few-sampled transaction(s), it extrapolates the effect to the whole heading or to the whole EU budget, which often amplifies the importance of such errors. Given its more detailed segmentation of expenditure according to risk profiles and control systems, the Commission, when detecting such errors, is able to extrapolate them more precisely to the population that is most likely to be affected. It is thus able to give a more nuanced view of the level of error across the payments made and to clearly identify the areas where improvements are needed. European Commission. Id. at 51.

${ }^{61}$ European Parliament, Resolution of 14 May 2020 on Discharge for the Financial Year 2018, Section III - Commission and Executive Agencies, paras. 78, 201 (May 14, 2020), https://www.europarl.europa.eu/doceo/document/TA-9-2020-0114_EN. html; Council of the EU, Recommendation of 18 February 2020 on the Discharge to be Given to the Commission for the Financial Year 2018, doc. 5760/20 ADD 1, Chapter 1, para. 4 (Feb. 18, 2020), https://www.consilium.europa.eu/media/ 42605/st06138-en20.pdf.

${ }^{62}$ See supra note 54.
} 
As "audits do not operate neutrally and have effects on the auditee," 63 they should not be oblivious to their impact and possible dysfunctional effects. Due to its uncertain interpretation, ${ }^{64}$ the "error rate" can be imbued with meaning to support stereotypical thinking and inconclusive faultfinding debates. As if "the errors reported indicate that the spending of the EU budget is seriously affected by fraud and corruption, adversely affecting public confidence in the EU institutions." 65

The "error rate" has become a benchmark for "success" and "blame," with the risk, on the one hand, to increase the scope of legal requirements beyond needs_-"gold-plating"-and, on the other hand, to "reinforce the existing conservatism of organizations which are aware of the unsympathetic political and media responses to perceived failure." 66 The "error rate" logic tends to give importance to what can be measured, rather than measuring what is important. It risks providing support for wrong incentives, and encouraging responsible managers toward "creative" compliance to maximize funds' absorption, ${ }^{67}$ rather than achieving results in line with the funding objectives. As it has been observed, "[a]lthough there may be some merit in doing the right thing badly, there is none whatsoever in doing the wrong thing well." 68

\section{Performance Reports: Room for Broader Coverage of EU Policy Objectives}

The ECA's special reports look into the achievement of policy objectives of the around thirty policy areas according to "value for money"-economy, efficiency, and effectiveness. ${ }^{69}$ The audit requires setting up criteria directly derived from legislation or based on best practices-for example, standard costs applied by technical professions-and which are appropriate given the economic context. This may involve the use of data from different sources. The ECA's work, focusing on the achievement of broader policy objectives, goes beyond a "lawful versus unlawful" or "right versus wrong" assessment. Its conclusions are not simple and clear-cut, putting emphasis on specific issues of concern.

A systematic and structured examination of performance across the different areas of EU spending has been developed since 2000. The ECA auditors have progressively built-up new skills and accumulated broad knowledge and capacity of analysis, often drawing on outside expertise. The ECA's special reports cover a range of subjects considered to be high impact because of their financial importance, forthcoming developments, and political and public interest. Between 2015 and 2020, the ECA has published 175 special reports. ${ }^{70}$ They generally attract significant attention from the media and institutional stakeholders.

The wide awareness of performance concerns created by the ECA's special reports has promoted the application of "value for money" in the budget implementation, a concept introduced by the Treaty of Rome (1957) but long neglected until the 1990s. The ECA's special reports have

\footnotetext{
${ }^{63}$ Michael Power, The Audit Society - Second Thoughts, 4 Int. J. Audit 116 (2000).

${ }^{64}$ Fidelma White \& Kathryn Hollingsworth, Audit, Accountability and Government 179 (1999).

${ }^{65} \mathrm{ECA}$, Making the Best Use of EU Money: A Landscape Review of the Risks to the Financial Management of the EU Budget, para. 3 (July 25, 2014), =https://www.eca.europa.eu/en/Pages/DocItem.aspx?did=30031. It is worth mentioning that the ECA published the "error rate" for the first three annual audit opinions-financial years 1994 to 1996-and discontinued this practice afterwards, until the 2006 annual audit opinion where it published the "error rate" for Cohesion. As from the 2007 annual audit opinion the "error rate" is also published for the other spending areas.

${ }^{66}$ Irvine Lapsley \& Jeremy Lonsdale, The Audit Society: Helping to Develop or Undermine Trust in Government?, in Administrative Justice IN ConTEXT 86 (Michael Adler ed., 2010).

${ }^{67}$ For example, in Cohesion policy projects found non-compliant can be substituted with other projects which have already incurred expenditure from national sources, thus raising doubt as to the added value of using EU funding for projects that would have been implemented anyway.

${ }^{68}$ Auditor General of Canada, Report to the House of Commons for the Fiscal Year Ended 31 March 1978, para. 5.1 (Nov 1978), https://archive.org/details/reportofauditorg7778cana/page/n7/mode/2up.

${ }^{69}$ Financial Regulation, supra note 23, at art. 33; see also supra note 43.

${ }^{70}$ See ECA, Audit Reports and Opinions, https://www.eca.europa.eu/en/Pages/AuditReportsOpinions.aspx?ty=Special\% 20report\&tab=tab4.
} 
become a key input of the discharge procedure-Treaty of Maastricht (1992). The Commission has furthermore been required under the Treaty of Lisbon (2007) to submit each year to the European Parliament and to the Council "an evaluation report on the Union's finances based on the results achieved." 71 This prompted the Commission to start in 2015 the "EU budget for results" initiative, whose aim is to put performance at the core of the EU budget and its implementation, which includes promoting a performance-centric culture. Hopefully, this will contribute to moving progressively away from the "error" centric culture discussed earlier. ${ }^{72}$

As acknowledged by the Commission's spending review, the increase in the number of spending programs over time has resulted in fragmentation, overlaps and inability to fully exploit the synergies between different funding sources. ${ }^{73}$ The ECA is well aware of the risk of poor crosscutting coordination, misalignment of objectives across policy areas, and double funding. ${ }^{74}$ Nevertheless, its special reports generally have a "vertical" focus and cover specific spending programs according to the areas of responsibility of its audit chambers. This provides a partial view of EU policies' achievements, especially in the case of mainstreaming cross-cutting priorities, such as "[c]limate change adaptation and mitigation" and "[b]iodiversity," that entail significant funding through numerous spending programs with similar objectives. ${ }^{75}$ Conversely, an "aerial view" across spending programs would allow assessing consistency over different intervention areas and reveal possible unintended outcomes. This would strengthen the impact of the ECA recommendations in improving the set-up and rationale of the programs concerned.

An adequate coverage of the broad range of administrative models implementing EU spending programs ${ }^{76}$ with different strengths and weaknesses represents a key factor to ensure the representativeness of the ECA performance audit work. Its special reports show, however, that audit visits take place typically in four to five member states - normally those states with the highest funding allocation. While financial importance is one sensible criterion, such limited number of member states visited reduces objectively the overall perspective of the ECA audit findings. The representativeness of the ECA samples is further limited when it includes countries with a regionalized structure, with the audit conducted in one or two regions only. As audit represents ultimately a learning process for the benefit of managers, a wider range of member states-and delegated bodies - could enhance knowledge for all interested parties, in particular concerning best practices. In turn, this could enlarge the scope-and therefore the effect-of the ECA recommendations beyond the member states visited.

\footnotetext{
${ }^{71}$ TFEU art. 318(2). For the latest report, see European Commission, supra note 59, at $\$ 1$.

${ }^{72} \mathrm{See}$ id., at $\$ 2.2$. See also the results of the ECA survey on performance culture at the Commission, reported in ECA, Annual Report Concerning the Financial Year 2017 (July 12, 2018), at paras. 3.34-3.36, https://www.eca.europa.eu/Lists/ ECADocuments/annualreports-2017/annualreports-2017-EN.pdf.

${ }^{73}$ This concerns spending programs such as Horizon 2020, the Connecting Europe Facility, the European Structural and Investment Funds, the European Fund for Strategic Investments, and Erasmus +. Similar difficulties have been noted between EU funds investing in human capital development as well as for "Asylum, Migration and Security" and the numerous instruments in the field of external action. European Commission, supra note 9, at 10-11.

${ }^{74} \mathrm{ECA}$, Future of the CAP, paras. 30, 40 (Mar. 19, 2018), =https://www.eca.europa.eu/en/Pages/DocItem.aspx?did=45498. More recently, in its Opinion 6/2020 (Sept. 7, 2020) Concerning the Establishment of a Recovery and Resilience Facility (RRF), the ECA has observed that RRF's objectives are common to other EU programs, which has advantages in terms of complementarity and synergy. See ECA, Opinion No 6/2020 of Sept. 7, 2020, Concerning the Proposal for a Regulation of the European Parliament and of the Council Establishing a Recovery and Resilience Facility, para. 11, 2020 O.J. (C 350) 1, https://www.eca.europa.eu/en/Pages/DocItem.aspx?did=54818. Nonetheless, it increases the risk of double funding and competition between different programs, in particular as the scheme will cover projects which are potentially eligible under other policy areas, such as cohesion, transport, energy, and research.

75“Climate change adaptation and mitigation" entails about $€ 30$ billion/year and twenty-four spending programs. "Biodiversity" involves about $€ 12$ billion/year and twelve spending programs. Most significant contributions for both priorities come from the Common agricultural policy, Cohesion, and the Horizon 2020 programs.

${ }^{76}$ This refers to member states' delegated bodies but also to actors like EU agencies, the European Investment Bank, third countries, and international organizations that also ensure the day-to-day management of EU funding.
} 


\section{To What Extent is the ECA Heard by the Addressees of its Recommendations?}

Once they become public, external audit findings are likely to attract wide attention and call for solutions. It is therefore of the outmost importance that the ECA observations come with workable recommendations for those called to action. These depend on a clear assessment of the causes of the problems uncovered - such as whether these problems refer to the design of spending systems and their management arrangements, or to somewhat negligent implementation due to lack of preventive action or failure to act. Indication of the level of significance of recommendations should also be part of such assessment. ${ }^{77}$ The extent to which the ECA recommendations are accepted and subsequently implemented can be considered an indicator of the EU external auditor effectiveness. ${ }^{78}$ Similar considerations have prompted the U.S. Government Accountability Office (GAO) to give public access to its database of open recommendations, identifying those warranting priority attention. The GAO even quantified the amount of public money saved by their work. ${ }^{79}$

As a reflection of the EU budget's multi-level management, and inspired by the wish to clarify who and what is addressed by each recommendation - and who is responsible for taking any initiative and competence for implementing them-the ECA makes a distinction between the Commission and the member states when the latter exercise delegated management functions. While the Commission generally regards recommendations addressed to member states as being outside its responsibility, their follow-up is not an ECA priority. ${ }^{80}$ This risks contributing to the ambiguity about responsibilities for the use of EU funds discussed earlier, and ultimately to the "immunity" of financial actors. ${ }^{81}$ This issue could possibly be examined within the framework of the cooperation between the ECA and national audit offices, ${ }^{82}$ the latter potentially being in a better position to carry out such a follow-up.

In a given year, the ECA issues a significant number of recommendations. For example, the thirty-five special reports published in 2018 contained 380 recommendations on a wide range of topics. Mostly addressed to the Commission, the latter accepted $78 \%$ of the recommendations. Yet, the ECA does not comment on the reasons for the Commission rejecting some recommendations, in particular concerning their feasibility and cost-effectiveness. ${ }^{83}$

For the last several years the ECA has published the degree of implementation of its recommendations. For 2019, it stated that $57 \%$ of the recommendations made in the annual report concerning the financial year 2015 and $76 \%$ of the 184 recommendations made in the twenty-five

\footnotetext{
${ }^{77}$ INTOSAI Standard 100, supra note 27, at paras. 29-30; INTOSAI Standard 4000, Compliance audit standard, para. 20, https://www.issai.org/wp-content/uploads/2019/08/Withdrawn-ISSAI-4000-to-4200-E.pdf; INTOSAI Standard 300, Performance Auditing Principles, paras. 27, 38, 40, https://www.intosai.org/fileadmin/downloads/documents/open_access/ ISSAI_100_to_400/issai_300/issai_300_en.pdf.

${ }^{78}$ As argued by Vogiatzis, what can be deemed a satisfactory-or even successful—compliance rate of recommendations is also an issue for an extra-judicial office like the Ombudsman which does not produce binding decisions. NikOS VogIATZIs, The European Ombudsman and Good Administration in the European Union 194-201 (2018).

${ }^{79}$ The GAO 2020 Performance and Accountability Report states that the Office saved $\$ 77.6$ billion for taxpayers, or a return of about \$114 for every dollar of their budget. See GAO's Scorecard-How we saved the federal government \$77.6 billion this year, WATCHBLOG (Nov. 16, 2020), https://blog.gao.gov/2020/11/16/gaos-scorecard-how-we-saved-the-federal-government77-6-billion-this/.

${ }^{80}$ For example, in its Annual Reports Concerning the Financial Year 2018, supra note 35, para. 3.73, and in its Report on the Performance of the EU Budget-Status at the End of 2019, supra note 20, para. 7.3, the ECA stated that it did not follow up the recommendations addressed to member states in the special reports published in 2015-48 recommendations-and 201638 recommendations. $I d$. One may note in this respect that the European Parliament has asked the ECA to "put in place an extended follow-up of its performance audit recommendations." See European Parliament, Resolution of 26 March 2019 On Discharge in Respect of the Implementation of the General Budget of the European Union for the Financial Year 2017, Section III - Commission and Executive Agencies, para. 243, (Mar. 26, 2019), https://www.europarl.europa.eu/doceo/document/TA-82019-0242_EN.html.

${ }^{81}$ See supra Section A.

${ }^{82}$ TFEU art. 287.3, sentence 3.

${ }^{83}$ In its Report on the Performance of the EU Budget-Status at the End of 2019, supra note 20, at Box 7.3, the ECA provides some examples of recommendations rejected by the Commission but supported subsequently by Parliament.
} 
special reports published in 2015 had been implemented by the Commission either in full or in most respects. ${ }^{84}$ In 2020, the ECA observed a similar situation for thirty-three special reports published in $2016 .{ }^{85}$ These figures, which do not include recommendations to member states, ${ }^{86}$ make no distinction on the basis of the significance of the subject matter- "critical, very important, important, desirable." There is also no explanation for the noteworthy discrepancy between the annual report and special reports. One may note in this respect that the annual audit opinion for 2019 issued a more negative compliance assessment—adverse opinion-than in the previous three years, when the ECA perceived signs of improvement in the management of EU finances. ${ }^{87}$

While the figures indicated above seemingly show a large degree of acceptance and implementation of the ECA's recommendations in performance reports, one should note, however, that as an illustration of the rather "reform adverse" environment observed earlier, ${ }^{88}$ key issues are repeatedly raised. For example, failure to comply with public procurement rules and state aid legislation is a perennial and significant source of error. The ECA performance reports refer regularly to: Difficulties caused by the input-based nature of spending schemes, based on resources spent rather than results achieved, and by the absence of meaningful indicators; the need for clarity about the purpose of the funding and its possible impact given the lack of critical mass for most spending programs; the broad objectives and the need to prioritize the measures; the absence of a specific EU dimension over and above current national measures; the non-availability of reliable information about what was actually achieved and the benefits brought. In several reports the ECA has concluded that good intentions for more and better performance-oriented spending remained on paper. ${ }^{89}$

Also, the ECA's plea for making the EAV a core objective of the next MFF and demonstrating such value as a critical condition for earning citizens' trust in the EU, ${ }^{90}$ has not received the attention that it deserved. The spending review carried out by the Commission in preparation of the next MFF 2021-2027 ${ }^{91}$ did not provide an assessment of each spending program based on the criteria that the Commission itself defined for EAV. ${ }^{92}$ The new programs' objectives, presented as narrative mission statements, are not quantified and lack specificity. Therefore, they do not provide much insight to guide future funding decisions by the EU legislator. The legislative proposals for the two main spending areas-agriculture and cohesion-do not witness a decisive shift towards value for money, in particular by translating high level policy objectives into operational objectives showing the results that the EU wishes to achieve, thus leaving to member states the responsibility to define strategic goals for the funds concerned. Ultimately, policy objectives follow the funding and not the other way around. ${ }^{93}$

\footnotetext{
${ }^{84}$ ECA, Annual Activity Report for 2019, at 53 (May 7, 2020), https://www.eca.europa.eu/lists/ecadocuments/aar19/aar19_ en.pdf.

${ }^{85} \mathrm{ECA}$, Report on the Performance of the EU Budget, supra note 20, at paras. 7.2-7.5.

${ }^{86}$ See supra note 80.

${ }^{87}$ ECA, Annual Report Concerning the Financial Year 2019, supra note 3535, at para. 1.46.

${ }^{88}$ See supra note 9.

${ }^{89}$ See ECA special reports 21/2012 (Nov. 14, 2012) and 11/2020 (Mar. 30, 2020) on public buildings' energy efficiency; special reports 8/2010 (Sept. 8, 2010), 5/2013 (May 29, 2013), 1/2015 (Jan. 28, 2015), 8/2016 (Feb. 24, 2016), 13/2017 (July 12, 2017), 19/2018 (June 13, 2018), 9/2020 (Mar. 11, 2020) and 10/2020 (Mar. 25, 2020) on transport infrastructures and networks; and special reports 16/2011 (Oct. 26, 2011) and 22/2016 (July 14, 2016) on nuclear decommissioning.

${ }^{90} \mathrm{ECA}$, Audit Strategy 2018-2020, supra note 12, at 4.

${ }^{91}$ European Commission, Spending Review, supra note 9.

${ }^{92}$ European Commission, Reflection Paper on the Future of EU Finances, supra note 3, at 9.

${ }^{93} \mathrm{ECA}$, The Future of EU Finances: Reforming How the EU Budget Operates, (Feb. 15, 2018), =https://www.eca.europa.eu/ en/Pages/DocItem.aspx?did=45198; ECA, The Commission's Proposal for the 2021-2027 Multiannual Financial Framework (July 10, 2018), https://www.eca.europa.eu/en/Pages/DocItem.aspx?did=46593; ECA, The Commission's Legislative Proposals for the Next Multiannual Financial Framework (MFF), (Feb. 14, 2019), https://www.eca.europa.eu/Lists/ECADocuments/RB_ MFF/RB_MFF_EN.pdf.
} 
This raises the question whether, like the GAO, the ECA should have an open data platform of its recommendations. Drawing public awareness to their importance and level of implementation would potentially induce better accountability from those responsible for action.

\section{EU Added Value and the ECA's Institutional Relevance}

Having highlighted the current challenges that the EU's budget multi-level implementation is facing, this section explores how the ECA could strengthen its role in order to ultimately enhance the whole accountability process.

All public office holders are indeed both servants of the public and stewards of public resources. They are accountable to citizens for their decisions and actions and must submit themselves to the scrutiny necessary to ensure this. ${ }^{94}$ Their relevance cannot be assumed per se, regardless of their performance. Earning trust implies for EU institutions to lead by example in applying the EAV principle of achieving through the EU level more and better results that member states acting alone. In particular, EU institutions should use public funds at their disposal "as efficiently and as effectively as possible, and according to the principles of sound financial management." 5

As an independent institution ${ }^{96}$ with extensive audit powers and large discretion in fulfilling its audit mandate, ${ }^{97}$ the ECA's relevance and legitimacy depends on its ability to make a difference and create value for society by responding to expectations, emerging risks, and changing circumstances. Specifically, the ECA's contribution to good governance as a credible voice to create incentives for beneficial change requires providing knowledge unavailable elsewhere, comprehensive analysis, and well-founded recommendations for improvement. ${ }^{98}$ Two issues seem relevant in this respect.

The ECA annual audit opinion, its priority task, provides a limited assurance on the use of EU funds. ${ }^{99}$ This refers in particular to the exclusion of "value for money" from its scope, the difficulty to wrap-up EU heterogeneous policy areas, and implementing arrangements in a percentage that cannot speak for itself, and the lack of information on the reasons underlying the established irregularities so as to take specific remedial action. The "error rate" based approach risks also to provide support for wrong incentives, at odds with the objective of achieving results in line with the funding objectives. Furthermore, the need for the current plurality of "error rates" by the ECA and the Commission is not established. ${ }^{100}$

As it will be discussed in the following paragraphs in section $\mathrm{D}(\mathrm{I})$, the ECA annual audit opinion should rely on a wider concept of compliance encompassing "value for money" and meaningfully redirect its focus on the operation of the internal control framework and the management information provided by the Commission.

\footnotetext{
${ }^{94}$ United Kingdom Committee on Standards in Public Life, The Seven Principles of Public Life, https://www.gov.uk/ government/publications/the-7-principles-of-public-life/the-7-principles-of-public-life-2.

${ }^{95}$ ECA special report 14/2017, supra note 35, at para. 6.

${ }^{96}$ TEU art. 13(1). The necessary cooperation with the Commission, its auditee, and with Parliament and Council that the ECA should assist "in exercising their powers of control over the implementation of the budget" — TFEU art. 287.4(4) — should respect the principle of institutional balance on which the Union is founded-TEU art. 13(2). Such principle, at the basis of the EU institutional system, provides that institutions shall act within the limits of the powers conferred on them and shall practice mutual sincere cooperation. See Nikos Vogiatzis, The Independence of the European Court of Auditors, 56 COMMON MKT. L. REV. 690-94 (2019).

${ }^{97}$ This is subject to the principle of "effet utile" requiring an interpretation of EU law that ensures its effective implementation. ECJ, Case C-223/98, Adidas, ECLI:EU:C:1999:500 (Oct. 14, 1999), para. 24, =https://eur-lex.europa.eu/legal-content/ HR/ALL/?uri=ecli:ECLI:EU:C:1999:500.

${ }^{98}$ INTOSAI-P 12, The Value and Benefits of Supreme Audit Institutions, principle 5, https://www.intosai.org/fileadmin/ downloads/documents/open_access/INT_P_11_to_P_99/INTOSAI_P_12/INTOSAI_P_12_en.pdf; INTOSAI Standard 100, supra note 2727 , at para. 20.

${ }^{99}$ See supra Section $\mathrm{B}(\mathrm{I})$.

${ }^{100}$ It is worth noting that there is no obligation, from either the Treaty or professional audit standards, for the ECA to establish its own "error rate."
} 
The concept of EAV - as seen in the introduction to this Article - is the cornerstone of the whole EU construction and embodies the raison d'être of the EU budget. The ECA's intention to proceed in the future towards assessing "if action at EU level was the best way to achieve the desired outcome and whether more or less EU-level intervention would be needed in view of the objectives of the funding or policy" is a most welcomed development. ${ }^{101}$ As observed further in Section D(II), the ECA's broad knowledge and capacity of analysis in performance audits would allow to operationalize progressively the EAV assessment. Such a new perspective would indeed "help EU citizens decide if they can trust EU institutions to deliver results for them"102 and potentially play a triggering effect in enforcing better accountability from those called to action.

\section{The ECA Annual Audit Opinion: A Focus on Assurance Provided by the Internal Control Framework}

While providing absolute "assurance" that expenditures comply with established rules and that funds are used to best effect is out of reach for both the external auditor and internal control, ${ }^{103}$ the latter is the most effective tool towards ensuring a high level of assurance. Indeed, unlike an external audit that intervenes by definition ex post, internal control is not one event or circumstance, but a built-in dynamic process that permeates an entity's activities. It can deploy its effects in the day-to-day management by taking timely corrective action in specific transactions or weaknesses of the systems themselves. This makes of an effective internal control the primary response to risks. ${ }^{104}$

Over the last twenty years, the EU budget's internal control arrangements have been the subject of significant investment and related costs ${ }^{105}$ triggering consequential progress notably by setting common principles and standards. Endorsing the ECA's recommendation to entrust internal controls with the task of providing assurance on legality/regularity and value for money, ${ }^{106}$ the EU framework lays out that, "pursuant to the principle of sound financial management," internal control systems shall be applied at all levels of management, and designed to provide: Reasonable assurance of achieving value for money of the operations; reliability of reporting; safeguarding of assets and information; prevention, detection, correction and follow-up of fraud and irregularities; and adequate management of the risks. ${ }^{107}$

As stated by the ECA, the application of such framework is founded on the Commission's supervision of decentralized bodies charged of the day-to-day management. ${ }^{108}$ The establishment, in April 2000, of the Internal Audit Service (IAS) ${ }^{109}$ has represented a milestone for such supervision because the IAS' primary objective is "to provide the Commission with assurance as to the

\footnotetext{
${ }^{101} \mathrm{ECA}$, Audit Strategy 2018-2020, supra note 12, at 7.

${ }^{102} \mathrm{Id}$. at 4.

${ }^{103}$ INTOSAI Standard 100, supra note 27, at para. 31; INTOSAI GOV 9100, supra note 56, at 8, 12.

${ }^{104}$ INTOSAI GOV 9100, supra note 56 , at 6.

${ }^{105}$ Most of the cost for managing and controlling EU funds is borne by member states. Estimates of these costs are provided in Commission's directors-general annual activity reports. ECA special report No. 7/2020 provides an overview of the costs of implementing Cohesion policy funds. See ECA, Special Report No 07/2020: Implementing Cohesion Policy: Comparatively Low Costs, But Insufficient Information to Assess Simplification Savings, (Apr. 16, 2020), https://www.eca.europa.eu/en/Pages/ DocItem.aspx?did $=53380$.

${ }^{106}$ ECA, Opinion 2/2004 on the "Single Audit" Model, para. 57 (Mar. 18, 2004), https://www.eca.europa.eu/Lists/ ECADocuments/SP0602/SP0602_EN.PDF.

${ }^{107}$ Financial Regulation, supra note 23, at art. 36.1. Article 63 of the same regulation details these requirements to budgetary implementation delegated to nominated bodies in the member states.

${ }^{108}$ ECA, Opinion 2/2004, supra note 106, at para. 39, annex III.

${ }^{109}$ Internal audit should be distinguished from internal control which is a system integrated into management structures, operating processes and procedures. See supra note 56. Internal audit is a function independent from management. The IAS is responsible for assessing the operation of internal control systems within Commission's departments and, more generally, of their performance in implementing policies, programs and actions with a view to bringing about continuous improvement. For an insight of the IAS main developments during the last twenty-years, see European Commission, The Internal Audit Service, Assurance and Advice, https://ec.europa.eu/info/ias-history/twenty-years-internal-audit-service-ias_en\#theiasinitsseconddecade.
} 
effectiveness and efficiency of the risk management, control and governance processes."110 As indicated by Middelhoek, a former ECA president, it was precisely the absence of a proper internal audit function providing assurance "as to the truth and fairness of the Commission's reporting" that conditioned the ECA's initial choice to base its annual audit opinion on its own direct testing of transactions, instead of examining reporting established by the Commission. ${ }^{111}$ Along the same lines, Power argued that

[I]f the Commission could demonstrate that it monitors and evaluates the activities of member states, then the Court could rely on this "internal audit" function and audit the reasonableness of this work .... This will make the external audit of the EU budget possible in a different way, a shift from sampling to systems. ${ }^{112}$

Time seems ripe for forfeiting the dividends of such a wide-ranging reform of financial management and control. With the aim that the ECA and Commission's work should complement rather than unnecessarily duplicate each other, the ECA could build its annual audit opinion on the assessment of the operation of the internal control framework as supervised by the Commission, whose effectiveness is currently outside the scope of its annual audit opinion. ${ }^{113}$ As discussed in the following sections, such new concept of audit opinion is based on two key reforms.

\section{Assessing the Reliance of Management Information}

In line with the ECA's goal to move towards an "attestation" approach, ${ }^{114}$ and subject to the necessary professional skepticism and professional judgement, ${ }^{115}$ the ECA's assessment should be concerned with how the Commission performs its supervisory functions, and in particular whether the management information it presents ${ }^{116}$ gives a "true and fair view" of the budgetary implementation, so as to underpin confidence of intended users.

To avoid confusion of duties, while drawing attention to possible material misrepresentations or inconsistencies in such reports, the ECA should not supplant the Commission by attempting to

\footnotetext{
${ }^{110}$ European Commission, Mission Charter of the Internal Audit Service of the European Commission, at 2, C(2020) 1760 final (Mar. 25, 2020). As required by its mission charter, the IAS provides annually an overall opinion on the state of financial management in the Commission.

${ }^{111}$ André Middelhoek, Performance Audits and Compliance Audits - The Challenge of the European Court of Auditors, $4 \mathrm{DE}$ AcCountant 266-67 (1995).

${ }^{112}$ Michael Power, The Audit Society: Rituals of Verification 89 (1997).

${ }^{113}$ ECA, Annual Report Concerning the Financial Year 2019, supra note 35, at para. XXVIII(b). While this is a primary duty of the internal auditor, external auditors have the responsibility of evaluating the effectiveness of the internal audit function. See INTOSAI GOV 9150, supra note 31, at paras. 1.6, 3.3.5.

${ }^{114}$ ECA, Annual Report Concerning the Financial Year 2019, supra note 35, at para. 1.32. "Attestation engagement" means providing - in the report - a conclusion on the information presented by the auditee on the basis of established criteria. This conclusion may include new information, analyses, or insights. See INTOSAI Standard 100, supra note 27, at paras. $40-42$.

${ }^{115}$ These interrelated concepts refer to auditors' questioning and independent minds, being alert to conditions indicative of possible misstatements due to error or fraud, and performing a critical assessment of audit evidence obtained throughout the audit. The aim is to reduce the risk to overlook key facts and using inappropriate assumptions in the audit conclusions. See INTOSAI Standard 100, supra note 27, at para. 37.

${ }^{116}$ This refers notably to programs statements, to the EU accounts, to directors-general annual activity reports, and to the annual management and performance report. In this respect, in line with its right to perform a continuous audit, with unrestricted access to any document or information it considers "necessary to carry out its task," the ECA may have to examine the internal processes leading to such reporting, prior to statutory publication deadlines. TFEU art. 287.3(1)(2); see also INTOSAIP 1, supra note 27, at para. IV.10.1; INTOSAI-P 10, Mexico Declaration on Independence, Principle 4, https://www.issai.org/ pronouncements/intosai-p-10-mexico-declaration-on-sai-independence/. One may note that in 2021 the ECA will report on the adequacy of the Commission's work and the reliability of its reporting on legality and regularity of Cohesion spending, as well as the closure of the ERDF/ESF 2007-2013 financial instruments.
} 
present different evidence through its own testing. As a result, the ECA's audit work should not aim to establish an "alternative" error rate to Commission's error estimates. ${ }^{117}$ This is typically a management instrument to set possible financial corrections-by the Commission and member states-for which the ECA has no role, not least because its findings are not binding. As a matter of fact, one should note that the Commission's overall estimate of error is slightly below that of the ECA. ${ }^{118}$ As discussed previously in Section $\mathrm{B}(\mathrm{I})$, the relevance of different estimates between the ECA and the Commission for multi-annual programs can only be assessed after the latter's final clearance.

The ECA should assess in particular the risks and estimates of error that the Commission establishes at two key stages in the budgetary implementation cycle, at payment and at closure, as well as the procedures in place to ensure that the "tolerable risk of error"119 is or can ultimately be respected after Commission's final clearance. This means that for the significant part of EU expenditure characterized by multi-stage payments spread over several accounting years, the ECA may have to perform, at closure, direct testing of final balances that are at much greater risk of error. The extent of such ECA testing would depend on the assurance provided at regular intervals throughout the program period, with a view to check the adequacy of procedures in place.

As for compliance, the ECA should assess, through appropriate testing, the degree of assurance about performance of EU spending. In this respect, the ECA annual opinion should assess the reliability and relevance of Commission's reporting, in particular the process underlying the report "on the results achieved". ${ }^{120}$ This would also provide the opportunity to evaluate the progress of the Commission's "EU budget for results" initiative. ${ }^{121}$

While the ECA has to establish an audit opinion each year, the reality is that the assurance may only be built on a multi-annual basis. Given the relative stability of the management and control framework within the programming period, the ECA could examine the different policy areas on a rotational basis, with a view to cover all of them within the MFF duration. This also means that the structure of the annual audit opinion may not be the same from year to year.

\section{Setting Appropriate Materiality Criteria}

Detecting every irregularity is not feasible, not least because of the prohibitive costs it would entail. Defining a materiality threshold above which the auditor would qualify its opinion involves a judgement on the needs of the users and the effect on decisions of the addressees of the audit opinion. ${ }^{122}$ While auditors set often materiality in terms of value only, ${ }^{123}$ the concept also involves qualitative aspects, such as the sensitive nature of certain transactions or programs, the public interest, the need for effective legislative oversight, and the type of irregularities. ${ }^{124}$

Being an authoritative pronouncement carrying reputational weight about what matters most, the way in which materiality is set by the external auditor can have a "cascade effect," as demonstrated by the fact that the ECA's current threshold has become the de facto standard for EU

\footnotetext{
${ }^{117}$ This is not required by the Treaties or by professional audit standards.

${ }^{118}$ For the financial year 2019, ECA and Commission error estimates are respectively $2.7 \%$ and $2.1 \%$. See ECA Annual Report Concerning the Financial Year 2019, supra note 35, at para. 1.34. Discrepancies exist for specific areas such as Competitiveness and Cohesion. It is worth mentioning however that the situation is subject to ups and downs from year to year (see supra note 52) and that different approaches create the conditions for divergence (see supra note 60).

${ }^{119}$ See supra Section $\mathrm{B}(\mathrm{I})$.

${ }^{120}$ See supra note 71.

${ }^{121}$ See supra Section B(III).

${ }^{122}$ Materiality serves as a determining factor for the nature and extent of sample sizes and the interpretation of the audit results.

${ }^{123}$ INTOSAI Standard 100, supra note 27, at para. 41.

${ }^{124}$ INTOSAI Standard 400, Compliance Audit Principles, para. 47, https://www.audit.gov.bz/wp-content/uploads/2018/06/ ISSAI-400-Fundamental-Principles-of-Compliance-Auditing.pdf; INTOSAI Standard 4000, supra note 77, at paras. 125-30.
} 
spending's compliance. ${ }^{125}$ This shows that the desire to promote a performance culture at both EU and member states level should go hand in hand with a wider concept of compliance encompassing "value for money." As a result, the concept of annual audit opinion sketched above, aiming ultimately at assessing the assurance provided by the EU budget management according to legality/regularity and value for money, would require the ECA to reconsider its definition of materiality. ${ }^{126}$ This would imply setting a materiality threshold beyond a purely quantitative benchmark, to integrate qualitative concerns of nature and context in a given spending area that should warrant consideration in the final assessment. This would avoid, as in the case of EU support for farmers' incomes, ${ }^{127}$ such expenditures being considered "free from material error" and, at the same time, an ineffective spending scheme.

Finally, the external auditor's materiality threshold should be distinguished from the concept of "tolerable risk of error." 128 The latter is a matter for the political authorities that may wish to give weight to policy imperatives, reputational risks or the benefit-to-cost ratio for reducing irregularities through more controls. Despite the current de facto equivalence between the ECA's materiality threshold and the "tolerable risk of error," these concepts are distinct and refer to different needs and responsibilities. Therefore, their definition does not have to be the same.

\section{Assessing the European Added Value and the Expectation Gap}

EAV represents the raison d'être of the EU budget and a condition for the legitimacy of the revenue raised to fund it. The expectation that "spending at EU level means a better deal for citizens than spending at national level," 129 a goal reflected in the Commission's duty to provide an evaluation report "based on the results achieved," 130 calls for evidence-based policy making. As observed by the ECA, "trust in the EU diminishes if added value is not demonstrated." 131

The ECA has long time advocated the need to embody the concept of EAV in a suitable political declaration or in EU legislation, with a view to provide criteria for the guidance of the Union's political authorities. ${ }^{132}$ The ECA further observed that this is necessary not only to allocate resources but also to design and evaluate spending programs on the basis of a comparison of their performance. ${ }^{133}$

Used in different contexts and with distinct meanings, the concept of EAV is still unspecified at EU political level. In the current framework where the MFF represents a compromise between different rationales and national stances, with funding spread across a large number of policy areas and spending programs, ${ }^{134}$ a firm definition of EAV could be seen by political authorities as a constraint rather than an opportunity. The fact that, as recalled earlier, ${ }^{135}$ the spending review carried out by the Commission in preparation for the next MFF 2021-2027 ${ }^{136}$ did not provide an assessment of each spending program based on the criteria that the Commission itself defined

\footnotetext{
${ }^{125}$ See supra Section B(I).

${ }^{126} I d$. The ECA uses for its annual audit opinion a $2 \%$ "one size fits all" materiality threshold across policy areas, independently from their risks and peculiarities.

${ }^{127} \mathrm{Id}$.

${ }^{128} \mathrm{ECA}$, Reflections on the Commission's Communication "Towards A Common Understanding of the Concept of Tolerable Risk of Error”, para. 3 (Apr. 3, 2009), https://www.eca.europa.eu/ga/Pages/NewsItem.aspx?nid=419; see also supra note 54 .

${ }^{129}$ European Commission, The EU Budget Review, supra note 4, at 5.

${ }^{130}$ See supra note 71 .

${ }^{131} \mathrm{ECA}$, Audit Strategy 2018-2020, supra note 12, at 4.

${ }^{132}$ ECA, Response to the Commission's Paper "Reforming the Budget, Changing Europe", paras. 7-9 (Apr. 11, 2008), https:// www.eca.europa.eu/en/Pages/AuditReportsOpinions.aspx?itemid $=41492 \&$ page $=2 \&$ itemDate $=20170531+08: 00: 00 \&$ itemDateFile $=\&$ ty $=$ Opinion; $\operatorname{tab}=$ tab6\&start $1=91$.

${ }^{133}$ ECA, EU Budget: Time to Reform? 2014-2020 MFF Mid-Term Review, paras. 17-18 (Nov. 3, 2016), https://www.eca europa.eu/en/Pages/NewsItem.aspx?nid=7763; ECA, The Commission's Proposal, supra note 93, at para. 26.

${ }^{134}$ See supra Section A.

${ }^{135}$ See supra Section C.

${ }^{136}$ European Commission, Spending Review, supra note 9.
} 
for $\mathrm{EAV}^{137}$ seems to confirm this stance. Furthermore, the fact that significant spending programs were approved in the absence of an impact assessment supports this stance as well. ${ }^{138}$ This shows that while being a popular subject for academic debate, this prominent concept is over-shadowed by other pressing priorities and is still too low in the "to-do" list of the EU's legislature.

The ECA has provided a definition of EAV in some of its special reports, ${ }^{139}$ encapsulating the key elements of this concept defined as "the value that an EU action adds through EU policy, regulation, legal instruments and spending, over and above that created by Member States acting alone." 140 This definition clarifies two key aspects. First, EU funding is only one among possible options of EU intervention. In fact, EU objectives are mainly pursued through legislative and coordination actions that are often the main drivers for bringing in line member states' economic, social, and political structures. Second, EAV has to be "over and above" national efforts. Such conditions exist when the actions of member states are not sufficient - known as the "criterion of need" — and when benefits are generated for the entire Union - known as the "effectiveness criterion." This means an added value beyond borders and benefits for a large part of the EU population. From an economic point of view, not only the benefits should exceed the costs of public spending. Those benefits should also be larger than those at the national level. Achieving value for money ${ }^{141}$ is therefore a necessary, although not sufficient condition for EAV.

The ECA has indicated the intention to "assess, whenever possible, if action at EU level was the best way to achieve the desired outcome and whether more or less EU-level intervention would be needed in view of the objectives of the funding or policy." 142 This opens the door to an assessment of the EAV that could be particularly helpful "in view of reform pressures on the EU," as the ECA itself pointed out.

The significant knowledge and capacity of analysis accumulated through its performance audits allows the ECA to move forward in defining progressively a standard performance assessment approach as a basis for operationalizing the EAV concept. In particular, in line with international audit standards and a "no surprises" approach, ${ }^{143}$ the ECA could examine with the Commission the specific elements bearing witness of EAV in a given spending area and develop accordingly the audit criteria that would permit to assess whether, and to what extent, EAV has been achieved in practice. Impact assessments and evaluations could provide relevant indications in this respect. Placing the EAV discussion at the operational level would probably facilitate the identification of what it is possible to demonstrate in practice, thus contributing to "deglamorize" a concept that is often used as a buzzword.

On the basis of the ECA's own recurrent findings, ${ }^{144}$ three levels of assessment seem pertinent. The starting point is whether EU funding bears witness to the established needs that are relevant

\footnotetext{
${ }^{137}$ European Commission, Reflection Paper on the Future of EU Finances, supra note 3, at 9.

${ }^{138} I d$. The ECA has pointed out the absence of impact assessment in several cases, for example: The European Fund for Strategic Investments; the common provisions for seven EU funds under shared management; the Just Transition Fund; the European Fund for Sustainable Development and also the Next Generation EU Instrument—for which exceptional circumstances apply.

${ }^{139}$ See, e.g., ECA Special Report, Cohesion Policy Funds Support to Renewable Energy Generation - Has it Achieved Good Results? (Apr. 9, 2014), https://www.eca.europa.eu/Lists/ECADocuments/SR14_06/SR14_06_EN.pdf; ECA, The External Borders Fund Has Fostered Financial Solidarity But Requires Better Measurement of Results and Needs to Provide Further EU Added Value (June 24, 2014), https://www.eca.europa.eu/Lists/ECADocuments/SR14_15/QJAB14015ENC.pdf; ECA, EU Support for Productive Investments in Businesses - Greater Focus on Durability Needed (Feb. 7, 2018), https://www. eca.europa.eu/en/Pages/DocItem.aspx?did=45388; ECA, A European High-Speed Rail Network: Not A Reality but an Ineffective Patchwork (June 13, 2018), https://www.eca.europa.eu/Lists/ECADocuments/SR18_19/SR_HIGH_SPEED_ RAIL_EN.pdf; ECA, special report, Farmers' Income Stabilisation: Comprehensive Set of Tools, But Low Uptake of Instruments and Overcompensation Need to be Tackled, supra note 49.

${ }^{140}$ ECA, special report, Farmers' Income Stabilisation: Comprehensive Set of Tools, But Low Uptake of Instruments and Overcompensation Need to be Tackled, supra note 49, at para. 49.

${ }^{141}$ See supra note 43.

${ }^{142}$ ECA, Audit Strategy 2018-2020, supra note 12, at 7.

${ }^{143}$ INTOSAI Standard 300, supra note 77, at paras. 27, 29. Nevertheless, the ultimate responsibility for setting audit scope and criteria should rest with the external auditor.

${ }^{144}$ See supra Section C.
} 
to EU objectives and could not be satisfied by regulatory instruments only. This implies ascertaining whether there are clear and specific objectives addressing those needs, compatible with both available funding - or "critical mass" - and the relevant regulatory frameworks-particularly in case of cross border measures. It would also be relevant to examine to what extent financial support is made conditional to deliver specific and measurable results, and it reflects the priority of the different types and areas of intervention-for example, through progressive co-financing rates. A second level of examination could be whether EU funds are used consistently within and across policy areas-i.e., whether there are risks of overlapping or duplication, taking account of other levels of intervention, such as the European Investment Bank and national and regional budgets. A key point in this respect is whether there are indications that EU funds are used as a substitute for national funds, thus releasing national resources for use elsewhere, or for measures that would have been undertaken anyway. A third level of examination could deal with sustainability of funded measures and durability of results.

The ultimate aim of such assessment would be to ascertain the degree of EAV of spending programs, as the Commission initially envisaged, ${ }^{145}$ and to check whether commitments for results-oriented spending have materialized. ${ }^{146}$ This would open up the prospect of an EAV "assurance" assessment by the ECA that would "increase accountability and allow for an informed public discussion on how the EU budget is used," opening the door to concerns and expectations of European citizens as a major factor in shaping future budgets. ${ }^{147}$

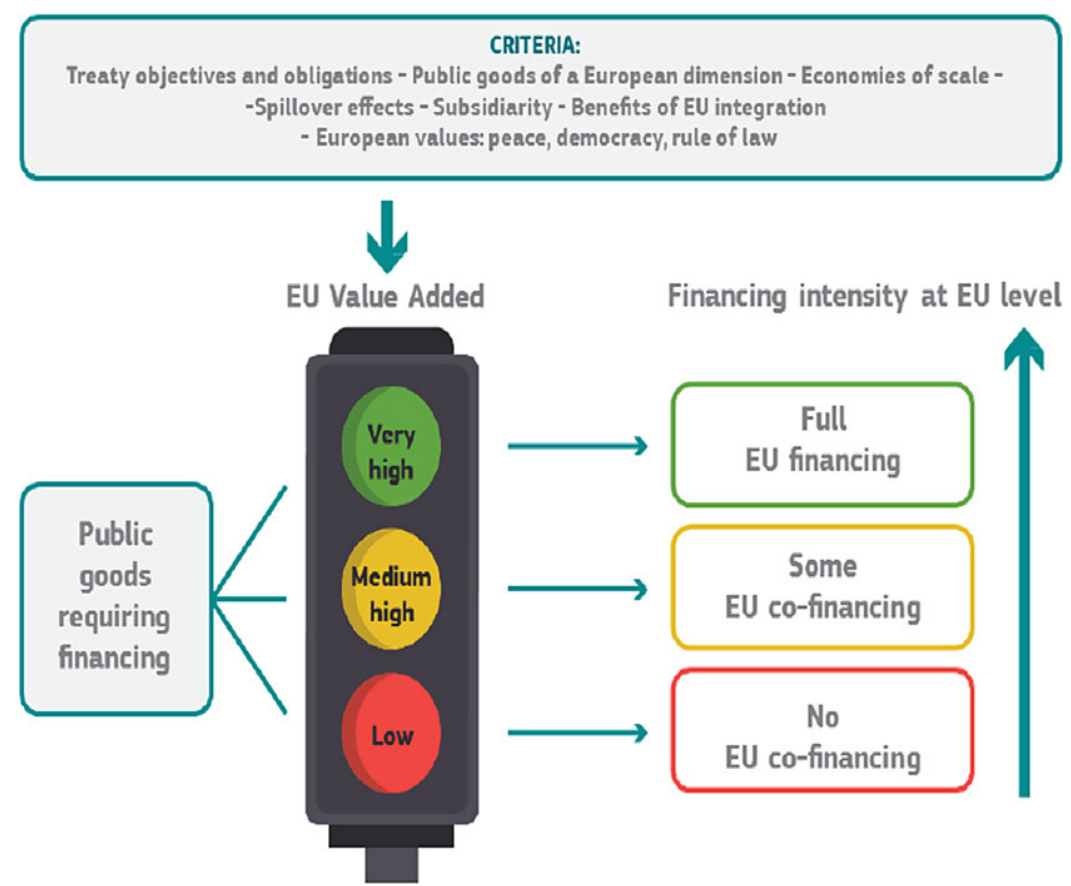

Figure 1. EU value added and funding from the EU budget ${ }^{148}$.

\footnotetext{
${ }^{145}$ See infra Figure 1.

${ }^{146}$ See supra Section C.

${ }^{147}$ European Commission, Reflection Paper on the Future of EU Finances, supra note 3, at 9-10.

${ }^{148}$ Source: European Commission, Reflection paper on the future of EU finances, supra note 3, at 9.
} 


\section{E. Conclusion}

As observed in the introduction to this Article, the EU budget has a unique nature. Mostly funded -although invisibly_-from national taxation, EU spending is set in a long-term plan with a large number of programs and objectives, yet concentrated on two main areas-agriculture and cohesion-for which member states nominated bodies ensure the daytoday management. The Commission, which is responsible for the budget implementation in all circumstances, manages directly less than one fifth of the funds.

Such framework is based on three main principles. As for any EU action, impact assessments should determine whether or not Union action is needed. In particular, EU spending is meant to achieve more than national spending alone, a concept known as European added value (EAV). Furthermore, EU spending should be managed at all levels according to common rules and standards. Delegated management bodies should have in place "internal control systems" designed to provide reasonable assurance that spending complies with legality, regularity, and value for money. The Commission should supervise the operation of such framework and report on the results achieved by EU spending. Finally, the European Court of Auditors (ECA) is responsible for auditing the budgetary implementation and reporting to the European Parliament and the Council, whose scrutiny culminates in the annual discharge procedure to be given to the Commission.

In practice, however, the notion of EAV is not defined at EU level, which provides the ground for applying different rationales. Impact assessments, at the heart of evidence-based policy and legitimacy of EU action, ${ }^{149}$ do not play as a strict filter for EU spending programs, in particular concerning translating high level political aims or policy objectives into operational objectives. In several cases, measures are not based on an impact assessment. ${ }^{150}$ The Commission has no active role in the budgetary implementation entrusted to delegated bodies and in the main management decisions they take, for which it discards responsibility. Its supervision, limited by its remoteness from the ground field, focuses on the respect of financial compliance, in other words, that irregularities do not exceed $2 \%$ of the expenditure. Concerning results achieved by EU spending, the Commission has to rely on third-parties' reporting whose reliability is uncertain. ${ }^{151}$ It has not been able so far to demonstrate convincingly that "spending at EU level means a better deal for citizens than spending at national level."152 This notwithstanding, the risk for the Commission to be refused discharge seems rather theoretical. ${ }^{153}$ The fact is that the Commission is given discharge each year despite the ECA standing qualification of the legality/regularity of the EU expenditure in the last twenty-five years and its recurrent criticism on EU spending's performance in all policy fields.

This Article examined the way in which the ECA discharges its responsibility for auditing EU funds. It observes that for several reasons ${ }^{154}$ the annual audit opinion, its priority task, provides a limited assurance. Furthermore, the approach based on "error rates" risks promoting the wrong incentives and ineffective protection of taxpayers' money. At the same time, this Article acknowledged the important and growing effort undertaken by the ECA to respond to the demand for performance assessment. It drew attention to the significant funding allocated to cross-cutting priorities where similar objectives apply to areas such as cohesion, transport, energy, and research.

\footnotetext{
${ }^{149}$ See supra note 3.

${ }^{150}$ See supra note 138. Currently one quarter of legislative proposals lack impact assessments and less than one third of impact assessments benefited from adequately prepared and properly used evaluations. ECA, Law-Making in the European Union After Almost 20 Years of Better Regulation, para. 9 (July 30, 2020), https://www.eca.europa.eu/Lists/ ECADocuments/RW20_02/RW_better_regulation_EN.pdf.

${ }^{151}$ The European Parliament repeatedly regretted the lack of endorsement by the Commission of the performance information it reports. See Resolution of 14 May 2020, supra note 61, at para. 105.

${ }^{152}$ European Commission, The EU Budget Review, supra note 4, at 5.

${ }^{153}$ Refusal of discharge only occurred twice, concerning the financial years 1982 and 1996.

${ }^{154}$ Notably, the exclusion of "value for money" from its scope, the difficulty to wrap-up EU heterogeneous policy areas and implementing arrangements in a percentage that cannot speak for itself, and the lack of information on the reasons underlying the established irregularities so as to take specific remedial action.
} 
The inherent risk of poor coordination and overlapping measures would recommend a scrutiny of spending programs across audit chambers' thematic responsibilities. Furthermore, this Article highlighted a limited geographical representativeness of performance reports, covering a handful of member states only. Finally, the picture provided by the ECA concerning the implementation of its recommendations seems too optimistic, because the lack, or inadequacy, of key conditions for ensuring "value for money" is recurrently raised in its performance reports. This Article also noted that the ECA's choice of addressing recommendations to member states has not yet resulted in an adequate follow-up. This raises the question of whether national audit offices should be involved in the follow-up process and, more generally, whether the ECA should have an open data platform of its recommendations to raise public awareness and induce better accountability from those responsible for action.

As a result of the Coronavirus pandemic, nothing has stayed the same. The unprecedented increase of EU funding decided for the period 2021-2027, amounting to more than $€ 1.800$ billion, means that already in $2021 \mathrm{EU}$ expenditure is expected to reach about $€ 380$ billion, complemented by up to $€ 133$ billion in loans to member states. The demand for accountability and protection of taxpayers' money will increase proportionally, as well as the risk of frustrated expectations betraying the public trust. As the ECA recently pointed out, providing funding to member states is not enough by itself, stressing the need of adequate administrative capacity to make good use of it. ${ }^{155}$

This will add a challenge to the ECA's already broad audit field with a growing number of financial instruments. Furthermore, it is not impossible that such audit field will be further expanded, following the ECA's claim that its audit remit should be extended to all bodies set up by the EU to implement EU policies — such as the European Defence Agency and the proposed European Monetary Fund - and bodies created through agreements outside the EU legal ordersuch as the European Stability Mechanism and the European Investment Bank in relation to its non-EU budget operations. ${ }^{156}$

In implementing its audit strategy, the ECA will be faced with difficult choices when allocating its audit resources - about 400 auditors, currently devoted for a significant part, at least $40 \%$ - to the establishment of the annual audit opinion ${ }^{157}$ which, as observed above, provides only limited assurance. This means that requests for additional staff to cope with the expansion of EU activities and finances cannot be dissociated from a review of the current auditors' allocation. Definitely, determining how much assurance is reasonable and ensuring cost beneficial audits is a matter of judgment. A critical issue, however, is the need to avoid-notably due to resource constraints - audits in certain areas that are adversely affected by the intensity of audits in other areas. For example, as noted earlier, there is a case for extending the horizontal view and the representativity of its performance audits, requiring most likely further resources. Ultimately, the allocation of audit resources to influential audit work, adding most value to support the EU achieving long-term benefits, will represent a touchstone for ECA's commitment to "act as a role model in financial management." 158

Acting "in the Union's general interest," 159 the large discretion the ECA enjoys in setting its audit mandate requires to give it a "useful effect," 160 in line with the EAV principle. There is a trade-off between the "intensity of checks on the one hand, and the benefit these procedures bring on the other." ${ }^{161}$ In particular, the ECA's relevance depends on its ability to make a difference and create value for society by responding to expectations, emerging risks and changing circumstances. In a rather reform adverse environment, the ECA can promote beneficial change by providing

\footnotetext{
${ }^{155}$ ECA, Opinion 4/2020, supra note 20 , at para. 8 .

${ }^{156}$ ECA, The Commission's Proposal, supra note 93, at para. 33.

${ }^{157}$ Gilberto Moggia, supra note 41, at 21.

${ }^{158}$ ECA, Decision 66-2011 Laying Down Ethical Guidelines, at 2.2 (Oct. 26, 2011), https://www.eca.europa.eu/en/ Documents/ANNEX-1.pdf.

${ }^{159}$ TFEU art. 285(2), sentence 2.

${ }^{160}$ See supra note 97.

${ }^{161}$ ECA, Opinion 2/2004, supra note 106, at para. 50.
} 
knowledge unavailable elsewhere, comprehensive analysis, and well-founded recommendations for improvement. ${ }^{162}$ For example, the development of the concept of "value for money" and the call for a performance culture or the introduction of an EU integrated internal control framework would not have materialized without the ECA's input.

Against this background, this Article makes two main proposals. The first ${ }^{163}$ concerns the ECA's annual audit opinion. Forfeiting the dividends of the significant efforts deployed in the last twenty years to develop an effective EU internal control framework, the ECA could build its audit opinion on the operation of such framework and the management information provided by the Commission. This would provide an assessment of the internal control framework, currently outside the scope of its annual audit opinion, thus fostering responsibility at management level. It would also counterbalance the current bias towards formal compliance, enlarging the scope of the annual audit opinion to "value for money" and hence sustaining the emergence of a performance culture. Finally, the enhanced use of management information will require less ECA direct testing, thus reducing the burden on audited bodies and beneficiaries.

The second proposal ${ }^{164}$ concerns the EAV of EU spending. The ECA's broad knowledge and capacity for analysis in performance audits would allow to operationalize progressively the EAV assessment by identifying specific constituent elements bearing witness of EAV in a given spending area and develop accordingly the audit criteria that would permit to assess whether, and to what extent, EAV has been achieved. This would open up the prospect of an EAV "assurance" assessment by the ECA that would indeed "help EU citizens decide if they can trust EU institutions to deliver results for them"165 and potentially play a triggering effect in enforcing better accountability from those called to action.

\footnotetext{
${ }^{162}$ INTOSAI-P 12, supra note 98, at principle 5; INTOSAI Standard 100, supra note 27, at para. 20.

${ }^{163}$ See supra Section D(I).

${ }^{164}$ See supra Section D(II).

${ }^{165}$ ECA, Audit Strategy 2018-2020, supra note 12, at 4.
}

Cite this article: Cipriani G (2021). Improving the Accountability of the EU Budget's Multi-Level Implementation: Strengthening the Contribution of the European Court of Auditors. German Law Journal 22, 466-489. https://doi.org/ $10.1017 /$ glj.2021.13 